\title{
Ovarian Stem Cell Nests in Reproduction and Ovarian Aging
}

\author{
Haifeng Yea,b Tuochen Zheng ${ }^{\mathrm{a}}$ Wei Lic Xiaoyan Li ${ }^{d}$ Xinxin Fu ${ }^{a, b}$ Yaoqi Huang ${ }^{a, b}$ \\ Chuan Hu ${ }^{a, b}$ Jia Lia,b Jian Huang ${ }^{a, b}$ Zhengyv Liua,b Liping Zheng ${ }^{a, b}$ \\ Yuehui Zheng ${ }^{a, b}$
}

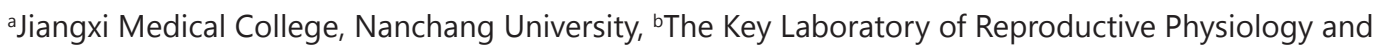
Pathology of Jiangxi Provincial, 'School of the 1st Clinical Medical Sciences, Jiangxi Medical College, Nanchang University, Nanchang, Jiangxi, dThe Second Affiliated Hospital of Nanchang University, Jiangxi, PR China

\section{Key Words \\ Ovarian stem cells $•$ Nests $•$ Reproduction $•$ Aging}

\begin{abstract}
The fixed primordial follicles pool theory, which monopolized reproductive medicine for more than one hundred years, has been broken by the discovery, successful isolation and establishment of ovarian stem cells. It has brought more hope than ever of increasing the size of primordial follicle pool, improving ovarian function and delaying ovarian consenescence. Traditional view holds that stem cell aging contributes to the senility of body and organs. However, in the process of ovarian aging, the main factor leading to the decline of the reproductive function is the aging and degradation of ovarian stem cell nests, rather than the senescence of ovarian germ cells themselves. Recent studies have found that the immune system and circulatory system are involved in the formation of ovarian germline stem cell niches, as well as regulating the proliferation and differentiation of ovarian germline stem cells through cellular and hormonal signals. Therefore, we can improve ovarian function and delay ovarian aging by improving the immune system and circulatory system, which will provide an updated program for the treatment of premature ovarian failure (POF) and infertility.
\end{abstract}

\section{Introduction}

Stem cell niche is also called stem cell micro-environment. Scientists have thoroughly researched the structure and functions of the stem cell niche in the hematopoietic system, intestinal system, neuronal cells, spermatogonia and the Drosophila ovary system [1-4]. However, further research remains to be conducted on the impact of mammalian ovarian stem cells and their aging on the ovarian nest functions. This paper discusses the composition of the mammalian ovarian stem cell nests, their characteristics and their influence on senescence of the female reproductive function.

Liping Zheng

and Yuehui Zheng,
Jiangxi Medical College, and The Key Laboratory of Reproductive Physiology and

Pathology of Jiangxi Provincial, Room 103, Administration Building, Nanchang University,

Nanchang, Jiangxi, (PR China); E-Mail stone91021@163.com; yuehuizheng@163.com 


\section{Cellular Physiology Cell Physiol Biochem 2017;43:1917-1925

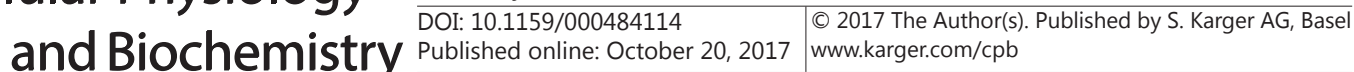 \\ Ye et al.: $\mathrm{OGSC}_{\mathrm{s}}$ Nests in Reproduction and Ovarian Aging}

\section{Research background and characteristics of ovarian germ stem cells}

The traditional view, which has lasted more than half a century states that the oocytes in major follicle pools of female mammals are fixed after birth and begin to decrease after puberty until they are depleted [5, 6]. However, in 2004, Johnson et al. [7] observed that the atresia follicles have a higher occurrence rate than reduction rate when they measured the number of the mouse follicle atresia conditions on different days. Therefore, he speculated that the ovary contains proliferative cells, which challenges the fixed follicle pool theory that monopolized reproductive medicine for a long time. Since then, scholars have used different methods to verify this discovery independently. Although there are a few scholars who doubt the mammalian ovarian stem cells theory $[8,9]$, researchers have verified the existence of ovarian stem cells in several mammals including humans using methods including stem cell isolation and purification, in vitro and in vivo transplantations, transgenic lineage tracing method, etc [10-18].

Ovarian germ stem cells are derived from bi-potential stem cells in the ovarian cortex and can produce new stem cells by symmetric division or differentiate into ovarian reproductive cells and primitive granular cells via asymmetrical division [19]. Ovarian germ stem cells appear round under a light microscope, with a diameter between 10-15 $\mu \mathrm{m}$. They are extremely rare and can be seen as groups or clusters when subcultured (Fig. 1). Additionally, they can express MVH, OCT4, Nango, Fragilis, Stella, C-kit and many other markers of reproductive cells and stem cells as determined via PCR. After obtaining training in Professor Ji Wu's laboratory of Shanghai Jiao Tong University and improving our culture techniques, our group has been able to expertly separate, purify and culture female ovarian stem cells, resulting in a solid foundation for female reproductive stem cells research [2022].

\section{The composition and the biological characteristics of ovarian stem cell nests}

The stem cell niche is the micro-environment where the surrounding stem cells survive, a concept that was proposed by Schofield [23] during a study of hematopoietic stem cells. He later found similar niche structures in the digestive system, nervous system, hair follicle glands and the sexual glands [24].

Fig. 1. Immunofluorescence of germ cells cultured in vitro with MVH and OCT-4. (Green: MVH; Red: OCT-4; Blue: Hoechst; Black: Bright field; Purple: Merge; Scale bars: $10 \mu \mathrm{m}$ ).

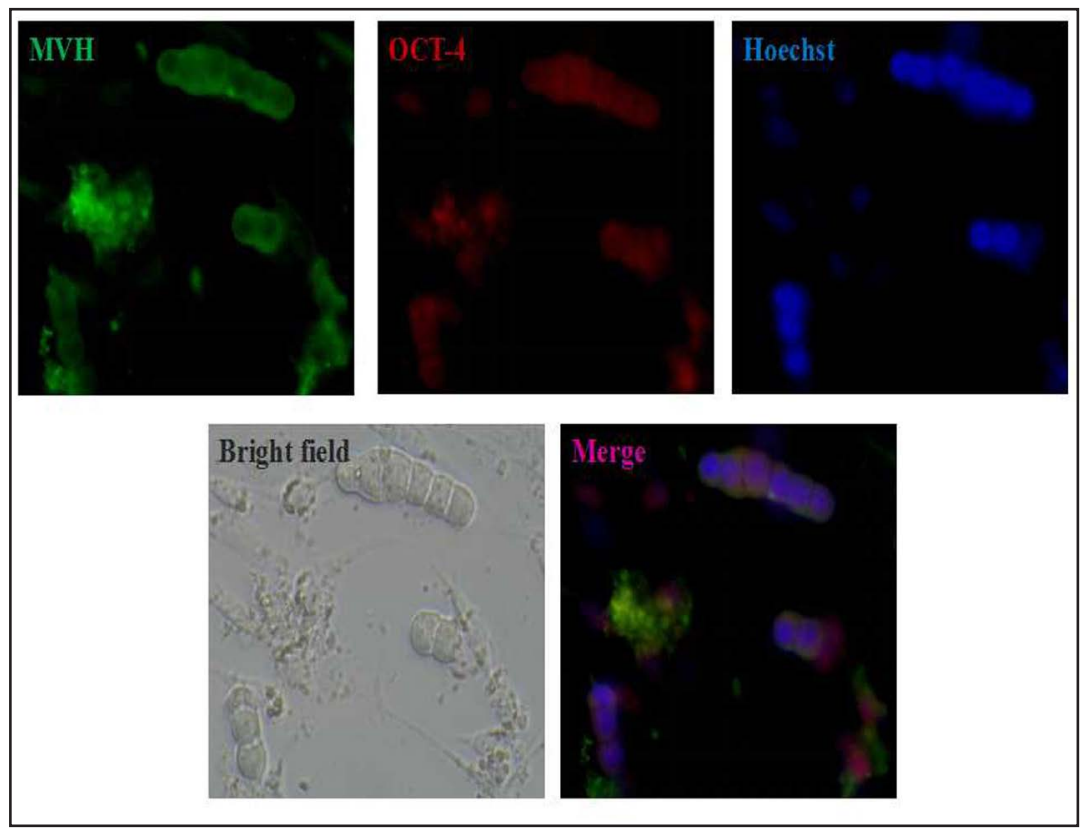




\section{Cellular Physiology Cell Physiol Biochem 2017;43:1917-1925 \begin{tabular}{l|l|l} 
and Biochemistry Published online: October 20, 2017 & $\begin{array}{l}\text { C) } 2017 \text { The Author(s). Published by S. Karger AG, Basel } \\
\text { www.karger.com/cpb }\end{array}$ \\
\hline
\end{tabular}

The stem cell niche is composed of niche cells, extra-cellular matrix and cytokines [25], and plays an important role in the histogenesis of the body's early development and tissue repair after birth. Ovarian stem cell nest, one of the indispensable components of ovarian stem cell niche, which is mainly composed of granulosa cells, vascular endothelial cells, immunologically relevant cells and molecules, surrounds the ovarian reproductive stem cells and regulate their functions (Fig. 2). Bukovsky [26] observed that the ovarian stem cell nest has been formed in the early embryonic development period and is composed of nonsite specific ovarian Monocyte-derived cells (MDCs), T cells and vascular endothelial cells whereas the adult ovarian reproduction stem cell nest is made up of primary MDCs (CD14+ MDC), activated MDCs (HLA-DR+ MDC), T cells, etc.

Relevant immunological cells and molecules in the ovarian stem cell nest are involved in the OGSCs' asymmetric division, contributing to the production of germ cells and regulating their symmetrical division, migration, the formation of new granule cells, as well as fetal and adult primordial follicles, which promote the selection and growth of the primordial follicles, including the formation of dominant follicles and subsequently, maintain the normal functions of ovaries. The conclusions are based on the following phenomenon of ovarian [27-29]: the immune relevant cells in the ovary rete tunnels, are necessary for the formation of ovary by OGSCs. Human embryonic ovary is determined by the evolution of the ovarian stem cells in the genital ridge peritoneal mesothelium, formed from the rete ovary in the mesonephric duct. Follicular development usually begins in the innermost layer of the ovarian cortex near the ovary rete, which is necessary for the development of ovary. Additionally, the ovarian network channels contains many immune system related cells such as some small and not presented mononuclear cells (MDC), which can be divided into a large number of activated MDC, responsible for the formation of ovary from the ovary rete with T cells. The immune cells are an important part of the OGSC nest and trigger the asymmetric fission of OGSCs. Fetal ovarian germ stem cell nest is composed of primordial germ cells, non-presenting monocytes and T lymphocytes. OGSCs (uncommitted OGSCs, u-OGSCs) are produced during the sixth week of pregnancy, before the arrival of the primordial germ cells (Primordial germ

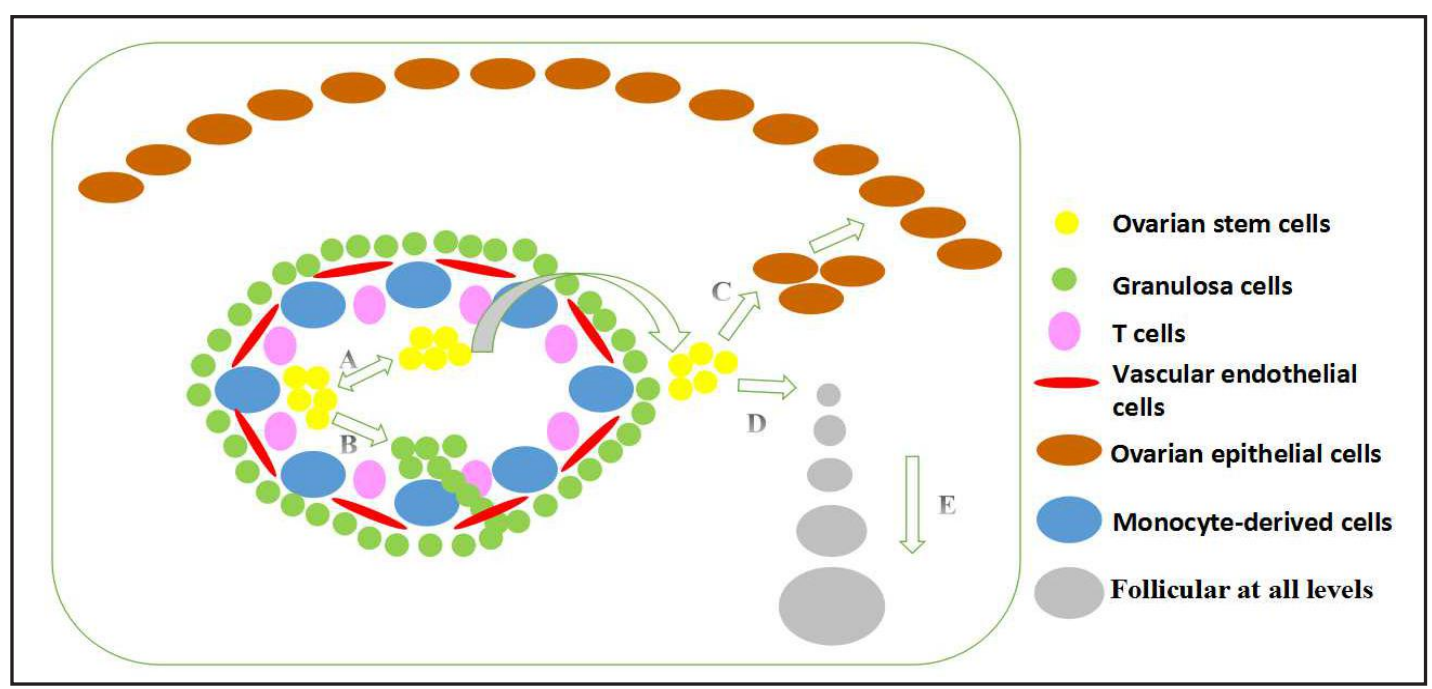

Fig. 2. The composition and function of ovarian stem cells nests. Ovarian stem cell nest is mainly composed of granulosa cells, vascular endothelial cells, immunologically relevant cells and molecules, surrounds the ovarian reproductive stem cells and regulate their functions. A: Ovarian germ stem cells self-proliferation B: Ovarian germ stem cells differentiate into granulosa cells C: Ovarian germ stem cells differentiate into ovarian epithelial cells that can compensate for ovarian epithelial loss when ovulation D: Ovarian germ stem cells differentiate into primordial follicles E: Primordial follicular development to follicles at all levels. 


\section{Cellular Physiology Cell Physiol Biochem 2017;43:1917-1925

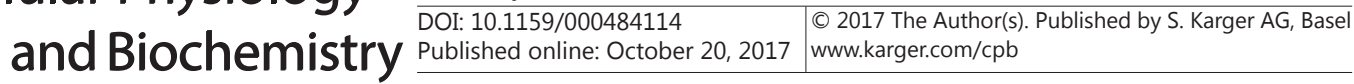 \\ Ye et al.: $\mathrm{OGSC}_{\mathrm{S}}$ Nests in Reproduction and Ovarian Aging}

cells, PGC) after which, the primordial germ cells invade the OGSC layer in the seventh week. OGSCs can only divide into secondary germ cells through asymmetric fission under the influence of both cellular signals (cellular signaling, CS; such as CD14 secreted by MDC and CD8 secreted by T lymphocytes) and hormonal signals (hormonal signaling, HS hCG; human chorionic gonadotropin and estradiol E2). Subsequently, the secondary germ cells enter the ovarian cortex and finally differentiate into oocyte cells (definitive oocytes, D0). The amount of OGSCs that are presented by MDCs and T cells determines the number of germ cells. The immune cells can also trigger the symmetrical fission of OGSCs and begin follicular growth until the decline of the immune system finally leads to the completion of follicle formation. When the primary CD14+MDC cells and T lymphocytes sometimes induce the OSE triggering the germ cells' symmetric division, the function of the immune system declined obviously between 35-40 years old and at the same time the follicles renewal stops.

\section{The effects of the ovarian stem cell nests aging on the ovarian aging}

Ovarian senescence is a complex physiological process involving the interaction and gradual accumulation of several factors, of which the most important aspects are the reduction in the number and quality of ovarian follicles [30,31]. Ovarian aging occurs faster than the aging of other organs, which not only affects reproductive health but also causes serious perimenopausal conditions and many age-related diseases [32-34], such as cardiovascular disease, cancer, osteoporosis, Alzheimer's disease, obesity and so on.

The old view states that the aging of the body and organs is due to the senility of the stem cells [35-37]. However, in recent years, some scholars indicate that the aging problem is more closely connected with the ageing of the stem cell nests [38,39]. In senescent individuals, in spite of the stem cells, the deterioration of the nest will finally result in the imbalance of the body's systems [40]. With increasing age, ovarian function cannot be maintained, despite the ovarian germ stem cell activity [41]. Niikura and his team discovered that the meiotic specific markers Stra8 and Dazl are highly expressed in non-ovulating older female mice [42]. Other scholars have successfully separated ovarian germ stem cells from the ovaries of the old rats, infertile mice and mice with premature ovarian failure [12]. Therefore, ovarian functions have are not directly associated with the existence of ovarian stem cells. In addition, after transplanting ovarian tissue of ageing mice into the ovaries of young mice, the primordial follicles were positive for GFP expression in the receptor mice; however, transplanting ovarian tissue of young mice into elderly mouse reduced the number of immature follicles in the transplanted tissue of the young mice [43]. These results indicate that ovarian function decline is mainly due to the aging of the ovarian germ cell nests but not due to the aging of the ovarian germ stem cells.

\section{Factors related to ovarian stem cell nests aging}

Ovarian germ stem cells belong to the category of adult stem cells. Currently, the majority of scholars believe that there are two mechanisms that contribute to adult stem cell aging. One of them is the endogenous mechanism, whereas the other one is related to the exogenous micro-environment (Fig. 3), which includes factors such as DNA damage, telomere shortening, elevated levels of reactive oxygen species, epigenetic modifications, changes in cell polarity, metabolism, micro-environments aspects and so on [44-48]. The aging of the exogenous micro-environment plays important roles both in leading to and accelerating the ovarian reproductive aging. The ovarian stem cell nests, one of the indispensable components of ovarian stem cell niche, is composed of intervascular compartments that connect the stem cells with the immune system and the circulatory system [49]. Thus, any functional change in the immune and circulatory systems may have an effect on the aging problems of the ovarian stem cells nests. 
Fig. 3. Schematic diagram of the mechanism of adult stem cell senescence. (Modified from Jung Y, Brack AS, Cellular mechanisms of somatic stem cell aging. Curr Top Dev Biol, 2014, 107: 405-438.).

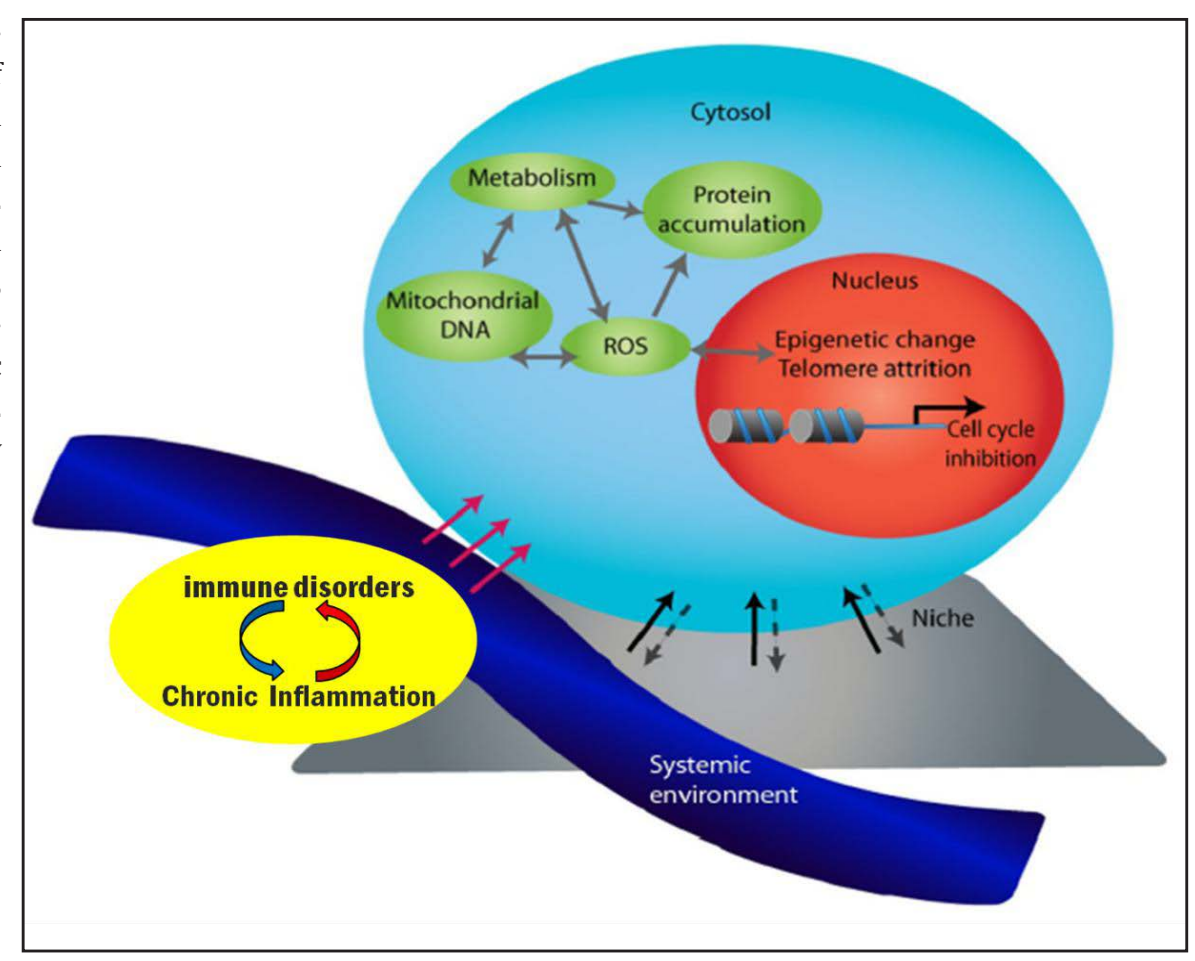

In 2005, Johnson et al. [50] proposed the existence of circulatory system stem cells that can replenish the follicle pools in the bone marrow and peripheral blood of adult female mice. Once this concept was proposed, several scholars questioned it. Kevin et al. [51] did not find the phenomenon of egg chimerism via the circulatory system in mice. In addition, after the CTtreated mice underwent the bone marrow transplantation, they still could not produce eggs. Therefore, Kevin successfully argued against the theory proposed by Johnson. In 2007, Lee [52] noted that the bone marrow transplantation could recover the reproductive functions of the CT treated infertile mice', but the resulting offsprings originated from the recipient mice germ line. Subsequently, some scholars stated that the bone marrow transplantation could repair damages to the ovarian functions caused by the chemotherapy drugs $[53,54]$. In recent years, researchers have found that ovarian stem cells are always accompanied by a few, very small, embryonic stem cells in the adult mammalian ovary [55-57], and these human embryonic stem cells are found in the peripheral blood of young, middle-aged and elderly people [58]. Virant et al. indicated that there is a potential connection between the VSELs and the germinal system as well as the hemapoiesis reconstruction process [59]. Veronique et al. [60] found that the "companion" blood cells are essential for the formation and the steady state of the ovarian germ stem cell nests. Therefore, we can conclude that the circulatory system is important for promoting ovarian functions.

The relationship between the immune system and the ovarian functions was discovered early, but little attention was paid to the effect of the immune system on the ovarian germ stem cell nests. Nishizuka et al. [61] found that mice developed ovarian hypoplasia after the removal of thymus in 2 to 4 day old, new-born mice. Russell et al. [62] discovered that thymus from normal female mice can suppress the superovulation induced by cyclophosphamide and X-rays. In 1979, Bukovsky [63] proposed for the first time, that the immune system played an important role in the regulation of ovarian function. In recent years, some scholars found that intramuscular injections of thymosin to new-born nude mouse can maintain the levels of follicle stimulating hormone (FSH) and luteinizing hormone ( $\mathrm{LH}$ ) in the serum during the time when the mice developed into adults, and additionally, they can inhibit ovarian hypoplasia of the nude mice [64]. In addition, researchers also found that with increasing age, the immune system inevitably degraded. First, the thymus function declines followed by 
a decline in ovarian function [27]. These results demonstrate that there is a close relationship between the immune system and the ovarian function. However, additional studies are needed to understand the exact changes in the ovarian stem germ cell nests brought about by the aging immune system as well as the specific mechanisms that are involved.

\section{The clinical significance of regulating ovarian germ cell nests aging}

People suffer from premature ovarian failure (POF) or perimenopause can improve the function of immune and circulatory system through diet, exercise and other health care products, which can indirectly provide a suitable micro-environment for aging ovaries. Therefore, the ovarian germ stem cells can remain active and continue to replenish the follicle pool. These measures can delay the female genital aging and relieve the symptoms associated with perimenopausal ovarian aging and other related senile diseases.

Through freezing eggs in the ovum bank before chemotherapy and radiotherapy, female adults can adopt assisted reproductive methods to remedy the infertility problems caused by cancer treatments. However, this method is not applicable for the pre-pubertal patients because oogenesis has not yet been initiated. For these patients, ovarian tissue can be partially resected before the cancer treatments and subsequently cryopreserved in the form of digested tissue suspension or single cell suspension. After these cancer patients completed their treatments, they can regain ovarian functions after puberty through transplantation of the frozen suspension liquid into the left ovary.

\section{Summary and prospect}

Aging is closely related to stem cell senility. In ovarian aging, the senility and degradation of the ovarian stem cell nests are thought to be the main factors leading to the decline of ovarian reproductive function, more so than the ovarian germ stem cells caducity. The immune and circulatory systems play vital roles in ovarian stem cell nests aging, however, the specific mechanisms need to be studied further. More recently, these factors have increasingly drawn people's attention to the decline in female reproductive function declining and perimenopausal related diseases caused by aging. Additionally, with the introduction of the two-child policy, it is of great significance to explore the mechanisms of ovarian aging. Furthermore, the study of delaying the ovarian aging process indirectly by improving immunity could provide us with useful information.

\section{Acknowledgements}

The authors would like to thank Dr. Liping Zheng and Dr. Yuehui Zheng for article mentoring, , We also thank the members in our lab who participated in this article. This work was supported by the National Nature Science Foundation of China (No. 81671455, 81360100, 81771583, 81260098, 81660245), the Natural Science Foundation of Jiangxi province (No. 20152ACB20023, 20161BAB205207, 20161BAB205213, 20153BCB23031).

\section{Disclosure Statement}

The authors declare no conflicts of interest.

\section{References}

1 Moore KA, Lemischka IR: Stem cells and their niches. Science 2006;311:1880-1885.

-2 Sugimura R: Bioengineering Hematopoietic Stem Cell Niche toward Regenerative Medicine. Adv Drug Deliver Rev 2016;99:212-220. 


\section{Cellular Physiology Cell Physiol Biochem 2017;43:1917-1925

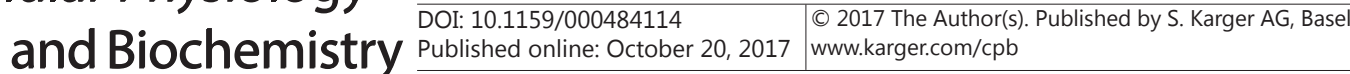

Ye et al.: OGSC $\mathrm{S}_{\mathrm{s}}$ Nests in Reproduction and Ovarian Aging

3 Hayakawa Y, Ariyama H, Stancikova J, Sakitani K, Asfaha S, Renz BW, Dubeykovskaya ZA, Shibata W, Wang HS, Westphalen CB, Chen XW, Takemoto Y, Kim W, Khurana SS, Tailor Y, Nagar K, Tomita H, Hara A, Sepulveda AR, Setlik W, Gershon MD, Saha S, Ding L, Shen ZL, Fox JG, Friedman RA, Konieczny SF, Worthley DL, Korinek V, Wang TC: Mist1 Expressing Gastric Stem Cells Maintain the Normal and Neoplastic Gastric Epithelium and Are Supported by a Perivascular Stem Cell Niche. Cancer Cell 2015;28:800-814.

4 Schewe M, Franken PF, Sacchetti A, Schmitt M, Joosten R, Bottcher R, van Royen ME, Jeammet L, Payre C, Scott PM, Webb NR, Gelb M, Cormier RT, Lambeau G, Fodde R: Secreted Phospholipases A2 Are Intestinal Stem Cell Niche Factors with Distinct Roles in Homeostasis, Inflammation, and Cancer. Cell Stem Cell 2016;19:38-51.

5 Pearl R, Fairchild TE: Studies on the Physiology of Reproduction in the Domestic fowl. Xix. of the Influence of Free Choice of Food Matrials on Winter EGG Production and Body Weight. Am J Epidemiol 1921.

6 Zuckerman S: The number of oocytes in the mature ovary. Recent Prog Horm Res 1951;63-108.

7 Johnson J, Canning J, Kaneko T, Pru JK, Tilly JL: Germline stem cells and follicular renewal in the postnatal mammalian ovary. Nature 2004;428:145-150.

8 Zhang H, Zheng WJ, Shen Y, Adhikari D, Ueno H, Liu K: Experimental evidence showing that no mitotically active female germline progenitors exist in postnatal mouse ovaries. P Natl Acad Sci Usa 2012;109:1258012585.

-9 Yuan JH, Zhang DD, Wang L, Liu MY, Mao J, Yin Y, Ye XY, Liu N, Han JH, Gao YD, Cheng T, Keefe DL, Liu L: No Evidence for Neo-Oogenesis May Link to Ovarian Senescence in Adult Monkey. Stem Cells 2013;31:25382550.

10 Zou K, Yuan Z, Yang Z, Luo H, Sun K, Zhou L, Xiang J, Shi L, Yu Q Zhang Y, Hou R, Wu J: Production of offspring from a germline stem cell line derived from neonatal ovaries. Nat Cell Biol 2009;11:631-636.

11 Zhang Y, Yang ZJ, Yang YZ, Wang SZ, Shi LJ, Xie WH, Sun KJ, Zou K, Wang L, Xiong J, Xiang J, Wu J: Production of transgenic mice by random recombination of targeted genes in female germline stem cells. J Mol Cell Biol 2011;3:132-141.

12 White YA, Woods DC, Takai Y, Ishihara O, Seki H, Tilly JL: Oocyte formation by mitotically active germ cells purified from ovaries of reproductive-age women. Nat Med 2012;18:413-421.

-13 Reizel Y, Itzkovitz S, Adar R, Elbaz J, Jinich A, Chapal-Ilani N, Maruvka YE, Nevo N, Marx Z, Horovitz I, Wasserstrom A, Mayo A, Shur I, Benayahu D, Skorecki K, Segal E, Dekel N, Shapiro E: Cell Lineage Analysis of the Mammalian Female Germline. Plos Genet 2012;8.

14 Virant-Klun I, Skutella T, Hren M, Gruden K, Cvjeticanin B, Vogler A, Sinkovec J: Isolation of Small SSEA-4Positive Putative Stem Cells from the Ovarian Surface Epithelium of Adult Human Ovaries by Two Different Methods. Biomed Res Int 2013;2013:690415.

15 Woods DC, White YAR, Tilly JL: Purification of Oogonial Stem Cells From Adult Mouse and Human Ovaries: An Assessment of the Literature and a View Toward the Future. Reprod Sci 2013;20:7-15.

16 Lu ZY, Wu M, Zhang JJ, Xiong JQ Cheng J, Shen W, Luo AY, Fang L, Wang SX: Improvement in Isolation and Identification of Mouse Oogonial Stem Cells. Stem Cells Int 2016;19:1-10.

17 Parvari S, Abbasi M, Abbasi N, Malek VG, Amidi F, Aval FS, Roudkenar MH, Izadyar F: Stem cell isolation by a morphology-based selection method in postnatal mouse ovary. Arch Med Sci 2015;11:670-678.

18 Parte S, Patel H, Sriraman K, Bhartiya D: Isolation and characterization of stem cells in the adult Mammalian ovary. Stem Cell Protoc 2015;1235:203-229.

19 Bukovsky A: Cell commitment by asymmetric division and immune system involvement. Prog Mol Subcell Biol 2007;45:179-204.

20 Li J, Zhou F, Zheng T, Pan Z, Liang X, Huang J, Zheng L, Zheng Y: Ovarian Germline Stem Cells (OGSCs) and the Hippo Signaling Pathway Association with Physiological and Pathological Ovarian Aging in Mice. Cell Physiol Biochem 2015;36:1712-1724.

-21 Pan Z, Sun M, Li J, Zhou F, Liang X, Huang J, Zheng T, Zheng L, Zheng Y: The Expression of Markers Related to Ovarian Germline Stem Cells in the Mouse Ovarian Surface Epithelium and the Correlation with Notch Signaling Pathway. Cell Physiol Biochem 2015;37:2311-2322.

22 Ye H, Li X, Zheng T, Hu C, Pan Z, Huang J, Li J, Li W, Zheng Y: The Hippo Signaling Pathway Regulates Ovarian Function via the Proliferation of Ovarian Germline Stem Cells. Cell Physiol Biochem 2017;41:1051-1062.

23 Schofield R: The relationship between the spleen colony-forming cell and the haemopoietic stem cell. Blood Cells 1977;4:7-25. 


\section{Cellular Physiology Cell Physiol Biochem 2017;43:1917-1925

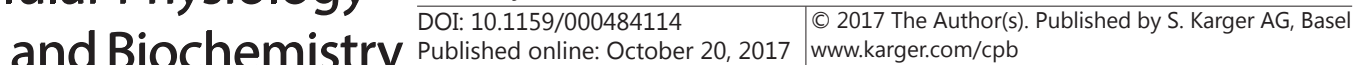

24 Fuchs E, Tumbar T, Guasch G: Socializing with the neighbors: Stem cells and their niche. Cell 2004;116:769778.

25 Lin HF: The stem-cell niche theory: Lessons from flies. Nat Rev Genet 2002;3:931-940.

26 Bukovsky A: Ovarian Stem Cell Niche and Follicular Renewal in Mammals. Anat Rec 2011;294:1284-1306.

27 Bukovsky A, Caudle MR: Immunoregulation of follicular renewal, selection, POF, and menopause in vivo, vs. neo-oogenesis in vitro, POF and ovarian infertility treatment, and a clinical trial. Reprod Biol Endocrin 2012;10.

28 Bukovsky A, Caudle MR, Virant-Klun I, Gupta SK, Dominguez R, Svetlikova M, Xu F: Immune Physiology and Oogenesis in Fetal and Adult Humans, Ovarian Infertility, and Totipotency of Adult Ovarian Stem Cells. Birth Defects Res C 2009;87:64-89.

29 Bukovsky A, Trebichavsky I, Zidovsky J, Presl J: Submicroscopic evidence of lymphoid cells within the granulosa of the rat atretic follicle. IRCS Med Sci 1978;6:80.

30 de Vet A, Laven JS, de Jong FH, Themmen AP, Fauser BC: Antimullerian hormone serum levels: a putative marker for ovarian aging. Fertil Steril 2002;77:357-362.

-31 Turola E, Petta S, Vanni E, Milosa F, Valenti L, Critelli R, Miele L, Maccio L, Calvaruso V, Fracanzani AL, Bianchini M, Raos N, Bugianesi E, Mercorella S, Di Giovanni M, Craxi A, Fargion S, Grieco A, Camma C, Cotelli F, Villa E: Ovarian senescence increases liver fibrosis in humans and zebrafish with steatosis. Dis Mod Mech 2015;8:1037-1046.

-32 Maki PM, Freeman EW, Greendale GA, Henderson VW, Newhouse PA, Schmidt PJ, Scott NF, Shively CA, Soares CN: Summary of the National Institute on Aging-sponsored conference on depressive symptoms and cognitive complaints in the menopausal transition. MENOPAUSE 2010;17:815-822.

-33 Pimenta F, Maroco J, Ramos C, Leal I: Predictors of weight variation and weight gain in peri- and postmenopausal women. J Health Psychol 2014;19:993-1002.

-34 van Rijn LE, Pop VJ, Williams GR: Low bone mineral density is related to high physiological levels of free thyroxine in peri-menopausal women. Eur J Endocrinol 2014;170:461-468.

-35 Signer RAJ, Morrison SJ: Mechanisms that Regulate Stem Cell Aging and Life Span. Cell Stem Cell 2013;12:152-165.

36 Jung Y, Brack AS: Cellular Mechanisms of Somatic Stem Cell Aging. Stem Cells Dev Dis 2014;107:405-438.

37 Nurkovic JS, Volarevic V, Lako M, Armstrong L, Arsenijevic N, Stojkovic M: Aging of Stem and Progenitor Cells: Mechanisms, Impact on the Therapeutic Potential and Rejuvenation. Rejuv Res 2015; ahead of print:

38 Mendelson A, Frenette PS: Hematopoietic stem cell niche maintenance during homeostasis and regeneration. Nat Med 2014;20:833-846.

39 Decarolis NA, Kirby ED, Wyss-Coray T, Palmer TD: The Role of the Microenvironmental Niche in Declining Stem-Cell Functions Associated with Biological Aging. Csh Perspect Med 2015;5:a025874.

40 Ryu BY, Orwig KE, Oatley JM, Avarbock MR, Brinster RL: Effects of aging and niche microenvironment on spermatogonial stem cell self-renewal. Stem Cells 2006;24:1505.

41 Tilly JL, Telfer EE: Purification of germline stem cells from adult mammalian ovaries: a step closer towards control of the female biological clock? Mol Hum Reprod 2009;15:393-398.

-42 Niikura Y, Niikura T, Tilly JL: Aged mouse ovaries possess rare premeiotic germ cells that can generate oocytes following transplantation into a young host environment. Aging 2009;1:971-978.

43 Massasa E, Costa XS, Taylor HS: Failure of the stem cell niche rather than loss of oocyte stem cells in the aging ovary. Aging 2010;2:1-2.

44 Jasper H, Kennedy BK: Niche science: The aging stem cell. Cell Cycle 2012;11:2959-2960.

45 Liang R, Ghaffari S: Stem Cells, Redox Signaling, and Stem Cell Aging. Antioxid Redox Sign 2014;20:19021916.

46 Adams PD, Jasper H, Rudolph KL: Aging-Induced Stem Cell Mutations as Drivers for Disease and Cancer. Cell Stem Cell 2015;16:601-612.

47 Fujimaki S, Wakabayashi T, Takemasa T, Asashima M, Kuwabara T: The regulation of stem cell aging by Wnt signaling. Histol Histopathol 2015;30:1411-1430.

48 Sui BD, Hu CH, Jin Y: Mitochondrial metabolic failure in telomere attrition-provoked aging of bone marrow mesenchymal stem cells. Biogerontology 2016;17:267-279.

49 Meirelles LD, Caplan AI, Nardi NB: In search of the in vivo identity of mesenchymal stem cells. Stem Cells 2008;26:2287-2299. 


\section{Cellular Physiology Cell Physiol Biochem 2017;43:1917-1925

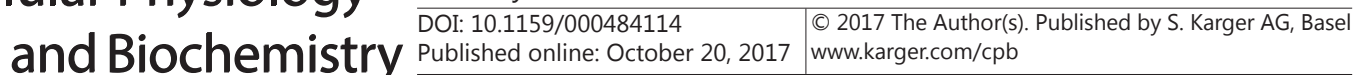 \\ Published online: October 20, 2017 www.karger.com/cpb}

-50 Johnson J, Bagley J, Skaznik-Wikiel M, Lee HJ, Adams GB, Niikura Y, Tschudy KS, Tilly JC, Cortes ML, Forkert R, Spitzer T, Iacomini J, Scadden DT, Tilly JL: Oocyte generation in adult mammalian ovaries by putative germ cells in bone marrow and peripheral blood. Cell 2005;122:303-315.

51 Eggan K, Jurga S, Gosden R, Min IM, Wagers AJ: Ovulated oocytes in adult mice derive from non-circulating germ cells. Nature 2006;441:1109-1114.

-52 Lee HJ, Selesniemi K, Niikura Y, Niikura T, Klein R, Dombkowski DM, Tilly JL: Bone marrow transplantation generates immature oocytes and rescues long-term fertility in a preclinical mouse model of chemotherapyinduced premature ovarian failure. J Clin Oncol 2007;25:3198-3204.

-53 Liang LX, Chao L, Deng XH, Yu HL, Liu WJ, Wang XP: Therapeutic effects of bone marrow transplantation on ovarian injury in mice. J Southern Med Univ 2011;31:1534.

54 Ghadami M, El-Demerdash E, Zhang D, Salama SA, Binhazim AA, Archibong AE, Chen XL, Ballard BR, Sairam MR, Al-Hendy A: Bone Marrow Transplantation Restores Follicular Maturation and Steroid Hormones Production in a Mouse Model for Primary Ovarian Failure. Plos One 2012;7:e32462.

55 Bhartiya D: Ovarian stem cells are always accompanied by very small embryonic-like stem cells in adult mammalian ovary. J Ovarian Res 2015;8.

56 Patel H, Bhartiya D: Testicular Stem Cells Express Follicle-Stimulating Hormone Receptors and Are Directly Modulated by FSH. Reprod Sci 2016;23:1493-1508.

57 Bhartiya D, Shaikh A, Anand S, Patel H, Kapoor S, Sriraman K, Parte S, Unni S: Endogenous, very small embryonic-like stem cells: critical review, therapeutic potential and a look ahead. Hum Reprod Update 2017;23:41-76.

58 Sovalat H, Scrofani M, Eidenschenk A, Henon P: Human Very Small Embryonic-Like Stem Cells Are Present in Normal Peripheral Blood of Young, Middle-Aged, and Aged Subjects. Stem Cells Int 2015;2016:1-8.

59 Virant-Klun I: Very Small Embryonic-like Stem Cells: A Potential Developmental Link Between Germinal Lineage and Haematopoiesis in Humans. Stem Cells Dev 2015;25.

60 Van de Bor V, Zimniak G, Papone L, Cerezo D, Malbouyres M, Juan T, Ruggiero F, Noselli S: Companion Blood Cells Control Ovarian Stem Cell Niche Microenvironment and Homeostasis. Cell Rep 2015;13:546-560.

61 Sakakura T, Nishizuka Y: Thymic control mechanism in ovarian development: reconstitution of ovarian dysgenesis in thymectomized mice by replacement with thymic and other lymphoid tissues. Endocrinology 1972;90:431.

62 Russell WR, Walpole AL, Labhsetwar AP: Cyclophosphamide: Induction of Superovulation in Rats. Nature 1973;241:129-130.

63 Bukovsky A, Presl J: Ovarian function and the immune system. Med Hypotheses 1979;5:415-436.

64 Goya RG, Reggiani PC, Vesenbeckh SM, Pleau JM, Sosa YE, Console GM, Schade R, Henklein P, Dardenne M: Thymulin gene therapy prevents the reduction in circulating gonadotropins induced by thymulin deficiency in mice. Am J Physiol-Endoc M 2007;293:182-187. 